\title{
O BELO ANTRO E A GRANDE OLIVEIRA: RECEPÇÕES DA ALEGORIA DA CAVERNA NA TRADIÇÃO NEOPLATÔNICA
}

\author{
Gabriele Cornelli*
}

\begin{abstract}
RESUMO
Desde a Magna Grécia de Pitágoras, Empédocles e Parmênides, passando pelas relações "perigosas" entre a sabedoria nascente e as tradições órficodionisíacas, em nítida continuidade com a mitologia arcaica e as narrativas teogônicas, dialogando com as práticas médicas asclepíades, a filosofia antiga visita cavernas. A caverna da República, uma das mais poderosas e fecundas alegorias do pensamento ocidental, é simultaneamente herdeira e ponto de fuga da longa trajetória dessa metáfora. Não se pretende aqui, no entanto, compreender a imagem platônica como a consumação de uma velha tradição filosófica que "pensa em cavernas"; procura-se, antes, iluminar essa alegoria com a interpretação oferecida pela filosofia acadêmica posterior. No Antro das Ninfas, Porfírio parte de 11 versos de Homero (Od. XIII, 102112) para habilmente desenhar uma exegese inspirada na teoria platônica da alma. A lectio porfiriana permite sugerir que a imagem da caverna revela algo mais que uma simples alegoria literária. Ela dá prova da existência de relações dialógicas e circulares entre a filosofia platônica e o imaginário religioso popular do mundo antigo.
\end{abstract}

Palavras-chave: Platão. Porfírio. Antro das Ninfas. Caverna. Neoplatonismo.

\begin{abstract}
Since the Magna Graecia of Pythagoras, Parmenides, Empedocles and passing by the "dangerous" relations between the nascent wisdom and orphic-dionisiacs traditions, in clear continuity with the archaic mythology and teogonical narratives, dialoguing with asclepians medical practice, ancient philosophy frequents caves. The cave of the Republic,
\end{abstract}

* Doutorado em Filosofia pela Universidade de São Paulo (USP). Pós-doutorado na Università degli Studi di Napoli Federico II. Professor do Departamento de Filosofia da Universidade de Brasília (UnB).E-mail: gabriele.cornelli@gmail.com 
one of the most powerful and fruitful allegories of Western thought, is simultaneously heiress and vanishing point of the long career of this metaphor. It is not intended here, however, understand the Platonic image as the consummation of an old philosophical tradition that "thinks in caves"; seeks rather to illuminate this allegory with the interpretation offered by later academic philosophy. In the Cave of Nymphs, Porphyry starts from 11 verses of Homer (Od. XIII, 102-112) to cleverly draw a platonic theory inspired exegesis of the soul. The lectio porfiriana allows to suggest that the image of cave reveals something more than a simple literary allegory. It gives evidence of the existence of relationships, dialogical and circular, between platonic philosophy and popular religious imagery of the ancient world.

Keywords: Plato. Porphyry. De Antro Nynfarum. Cave. Neoplatonism.

\section{Introdução}

Apesar de muita manualística normal da história da filosofia antiga comumente atribuir estas ligações perigosas da filosofia antiga com as práticas katabáticas àquele período de decadência e enfraquecimento da razão, de failure of nerves - na célebre definição oxoniana de Gilbert Murray - ou de irracionalismo sistemático, na correção à mesma feita pelo seu discípulo e sucessor, Eric Doods (HANKEY, 2005), com que é facilmente etiquetada a Antiguidade tardia, ao contrário, já desde a Magna Grécia de Pitágoras, Empédocles e Parmênides, passando pelas relações "perigosas" entre a sabedoria nascente e as tradições órfico-dionisíacas, em nítida continuidade com a mitologia arcaica e as narrativas teogônicas, dialogando com as práticas médicas asclepíades - desde então, dizia - a filosofia antiga visita cavernas. Por compreender o exercício da katábasis como um itinerário fundamental para a formação do homem sábio.

Até a mais célebre de todas as cavernas, quase que paradigma literário e filosófico de todas as outras: a caverna da alegoria platônica do V livro de República, uma das mais poderosas e fecundas alegorias do pensamento ocidental.

Não pretendo aqui, porém, compreender a imagem platônica como a consumação de uma tradição filosófica que "pensa em cavernas". 
Dediquei recentemente um artigo (CORNELLI, 2007b) a esta geofilosofia das cavernas.

A ideia é, antes, a de seguir adiante com esta busca pelas cavernas filosóficas, ao mesmo tempo voltando para o lugar onde havia começado: os textos da recepção da filosofia platônica em época posterior. Notadamente, me dedicarei aqui à recepção da imagem da caverna de Platão por Porfírio, que no Antro das Ninfas (AN), com o pretexto da descrição homérica, na Odisséia, do antro de Ítaca (XIII, 102-112), elabora uma exegese inspirada na teoria da alma de matriz platônica.

Antes disso, todavia, será necessário antepor algumas observações sobre a práxis exegética e alegórica tanto de Porfírio como do médio e neoplatonismo em geral, assim como umas brevíssimas observações sobre o percurso intelectual do autor em questão.

\section{Porfírio e a exegese alegórica}

O Antro das Ninfas de Porfírio é o único exemplo de comentário alegórico antigo de um texto poético que chegou até nós completo. Sua importância para a exegese alegórico-filosófica é, desta forma, indiscutível. Isso não significa que a prática alegórica fosse algo marginal no interior das atividades de produção filosófica: ao contrário, a história da literatura filosófica antiga está profundamente marcada por esta prática. A começar por Parmênides e sua alegoria da katábasis de Ulisses no proêmio do Poema, à qual Havelock (1958) dedicou inicialmente sua atenção, e mais recentemente Muniz (2007); para terminar no caso mais recente, do ponto de vista da sua descoberta, em 1962, do Papiro Derveni, ainda mais significativo por não resultar de uma traditio normal, e sim de um achado arqueológico. ${ }^{1}$ Depois de uma primeira parte dedicada ao desenho

\footnotetext{
1 Para um estudo mais aprofundado do papiro, cf. as atas de um recente colóquio realizado em Princeton (LAKS; MOST, 1997). Um grupo de estudiosos liderado por Pierris e Obbink, com a ajuda da moderna tecnologia de imagem multispectral a raios infravermelhos, em colaboração com a Bringham Young University, está empenhado em um paralelo estabelecimento do texto. Para os impactos da descoberta para o estudo do orfismo pré-platônico, cf. especialmente Burkert (1982, 2005), Kingsley (1995), Betegh (2004), Tortorelli Ghidini (2000, 2006), Bernabé (2002; 2007a). Entre outros papiros recentemente descobertos, vejam-se especialmente o Papiro de Bologna e diversos papiros
} 
de uma escatologia de matriz órfica e vagamente ctônica, a segunda parte do papiro é uma exegese de mitos órficos extraordinariamente consoante com a porfiriana que examinaremos em breve, e contém citações e referências indiretas a Heráclito, Anaxágoras, Diógenes de Apolônia e outros (GAZZINELLI, 2007). Não é irrelevante notar que o consenso atual sobre a datação original do papiro indica ser este mais antigo do que o IV século a.C. e, portanto, ainda "pré-socrático" (KOUROMENOS; PARÁSSOGLOU; TSANTSANOGLOU, 2006).

Como no exemplo do Poema parmenídeo, Homero foi, na Antiguidade, o autor mais elegido para este exercício da alegoria. Já definido por Platão como "o maior poeta e primeiro entre os autores trágicos" (Resp. 607a), começa tradicionalmente a ser defendido das acusações de impiedade e dos ataques racionalistas de autores como Heráclito e Xenófanes já na segunda metade do século IV, por Teagenes de Régio. Recentemente, todavia, o testemunho de Porfírio que atribui a Teagenes o primeiro movimento de defesa de Homero no "processo colossal" (PsHeráclito, All. Hom., 1,1) que ele sofreu no mundo antigo, foi colocado em discussão por diversos comentadores, que preferem atribuir esta primeira apologia em sentido alegórico aos pitagóricos do IV século (SIMONINI, 2006, p. 10). De fato, a busca por um sentido escondido (hypónoia) do texto remete certamente a Pitágoras e aos pitagóricos, que se utilizavam amplamente de uma linguagem iniciática e simbólica (Jâmblico. VP 104, 105; Porfírio VP 41, 42). "O que conta aqui é a invenção da hypónoia como a primeira defesa da poesia diante dos ataques da crítica filosófica. Tratava-se então de mostrar um Homero mais piedoso e afinado com as cosmologias em voga" (MUNIZ, 2007, p. 40).

De toda forma, a prática da exploração alegórica da simbologia acompanha diversos âmbitos da sabedoria antiga, incluindo neles as práticas oneirocríticas ou de interpretação de sonhos, frequentemente ligadas ao mundo da cura asclepíade, a mântica ou adivinhação; por restar em âmbito literário, a alegoria atravessa praticamente todo o arco do mundo antigo, acabando por influenciar a tradição exegética alexandrina dos textos bíblicos, como será o caso de Fílon.

mágicos gregos. Para uma resenha das descobertas de novos fragmentos órficos após a segunda guerra mundial, Bernabé (2000). 
Assim, no caso específico, a tradição médio e neoplatônica procura encontrar uma conjunção entre Platão e Homero: o segundo é expulso da cidade pelo primeiro, junto com suas histórias "que tenham ou não um sentido escondido (hypónoia) (Resp. II 378d)". Consegue este encontro exatamente explorando, por assim dizer, a plurivocidade do tex to platônico: na página anterior do texto de República (II 378a), Sócrates afirmava que "se houver alguma necessidade de falar [das histórias homéricas], que sejam escutadas em segredo por pouquíssimas pessoas". Sob este pretexto Plotino poderá restituir ao mito o sentido pedagógico de dizer o indizível (Enéadas 5.1.7), de se constituir como imagem-espelho do modelo-ideia, em condições de mostrar ao menos sua aparência (Enéadas 4.3.11). O mito se torna assim um mistério a ser desvendado por uma prática filosófica que se enreda por um itinerário de iniciação. Novamente, o próprio Platão, em vários loci, parece sugerir também isso (Fedro 249 c; Simpósio 209e-210a). Logo, autoproclamados herdeiros indiscutidos do mestre mistagógico Platão - nas palavras de Dodds - os neoplatônicos viveram a “fusão singular de humanidade e ascetismo, poesia e lógica, espírito crítico e religioso que constitui o caráter platônico" (DODDS, 1923, p. 8).

Neste âmbito histórico-filosófico insere-se a alegoria da caverna de Porfírio.

Quatro grupos de fontes recolhem informações sobre a vida do filósofo: suas obras, de maneira especial sua Vida de Plotino e a Epistula ad Marcellam, a biografia de Eunápio, contida nas Vitae Sophistarum, Eusébio e o verbete a ele dedicado na SUDA (BIDEZ, 1913).

De origens nobres, nasce na cosmopolita Tiro (232-233 d. C.), na Fenícia, onde entra em contato com a diversidade religiosa e literária que tanta parte terá no desenvolvimento de sua polymathía: conhece o hebraico e a literatura religiosa judaica, inicia-se com toda probabilidade aos mistérios (persa e egípcios), conhece os Oráculos Caldeus, a astrologia e a demonologia. Estuda inicialmente com Orígenes, na Palestina. Este último - conforme Eusébio - ao estudar Numénio, Crônio, Cornuto e outros acadêmicos "iniciou-se àquela interpretação alegórica (metaleptikón) dos mistérios dos gregos, e aplicou o método às escrituras dos judeus" (EUSÉBIO. História Eccl. 6,19,8). 
Significativo é o escrito ainda juvenil Sobre as imagens (Perí Agalmáton): lançando mão da iconografia clássica e, não somente ela, da religião grega, o texto articula astrologia, orfismo, platonismo, estoicismo e cultos orientais para interpretar os significados simbólicos das divindades.

Sua metodologia alegórica é anunciada programaticamente no início da obra

Falarei para aqueles que ouvirão com justiça: "vão-se vocês todos profanos e fechem as portas!”. (...) Mostrarei aos que aprenderam a leitura das estátuas, como dos livros, as coisas ali escritas sobre os deuses. Não deve maravilhar o fato dos ignorantes considerarem as estátuas como madeira e pedra; da mesma forma aqueles que não compreendem as palavras escritas olham para os monumentos como para simples pedras, para as tábuas escritas como pedaços de madeira, e para os livros como papiros costurados (PORFÍRIO, Sobre as imagens fr. 1,1-10). ${ }^{2}$

A ideia central, metodológica, é que com a chave hermenêutica adequada é possível operar uma síntese entre pensamento filosóficoracional e iconografia místico-religiosa e... fazer até as pedras falarem!

Porfírio continua os estudos em Atenas, na escola de Cássio Longino, orador, e neste período dedica-se a escrever comentários alegóricos da Ilíada e da Odisséia e um primeiro livro de uma história da filosofia, da qual sobreviveu somente a primeira parte: a Vida de Pitágoras.

Aos trinta anos, Porfírio vai para Roma, entra na escola de Plotino e torna-se em breve seu mais estreito colaborador. Mas a intensidade da pesquisa e a dura ascese imposta pela escola plotiniana conduziram Porfírio à beira do suicídio, mergulhado em uma grave crise melancólica: um diálogo de grande doçura entre o mestre e o discípulo sobre a situação delicada é imaginado com grande habilidade por Giacomo Leopardi em suas Operette Morali. O que sabemos é que Porfírio, por sugestão de Plotino, afasta-se da escola e transcorre na Sicília, de 268 a 271, um período de extensa produção literária, dedicada principalmente à teurgia

2 A tradução é minha. Consultei a tradução de E. H. Gifford. 
(De regressu animae) e a uma tentativa de harmonização entre os Oráculos Caldeus e a filosofia platônico-plotiniana.

Volta para Roma após a morte de Plotino e assume a direção da escola. Dedica-se então à publicação de diversos comentários de diálogos platônicos, à organização das obras de Plotino, e a este período parece pertencer o Antro das Ninfas (BIDEZ; BUFFIÈRE; BEUTLER, apud SIMONINI, 2006, p. 30). Todavia, a bem da verdade, nada impede datar o texto antes do encontro com Plotino, motivo pelo qual seria "melhor limitar-se a um non liquet" - é a sugestão mais sóbria de Turcan (TURCAN, 1975, p. 64).

Enfim, para quem interessar, casou com Marcela, viúva de um amigo e já mãe de sete filhos, e teve visão extática do divino somente uma vez, aos 68 anos de idade, cf. admite ele próprio em sua Vida de Plotino (23).

\section{O Antro das Ninfas}

O esforço exegético-alegórico que empenha Porfírio sobre o antro das Ninfas da Odisséia possui um precedente ilustre no trabalho do siriano Numênio de Apaméia. O próprio Porfírio o cita e comenta o texto deste amplamente em seu Antro (AN 21, 24, 28-34), mas não sabemos praticamente nada dele, afora que era um filósofo neoplatônico (ou neopitagórico?) que era lido na escola de Plotino de maneira tão intensa ao ponto deste último ter sido acusado de plágio do primeiro (Vida de Plotino 14).

Em resumo, os 11 versos de Homero são a ocasião para uma interpretação alegórica do antro das Ninfas (e de toda a Odisséia), no sentido de um dos temas centrais para a filosofia neoplatônica (e neopitagórica): a descida da alma no exílio da terra para a geração e sua volta em direção à verdadeira pátria. Assim, o antro torna-se simbolicamente o lugar cósmico da katábasis da alma, de sua geração no ciclo da metemsomatose. Logo, a compreensão de todos os elementos presentes na descrição homérica acaba fortemente entrelaçada por este pano de fundo do drama da alma. A trama deste tecido alegórico articula, com o estilo eclético típico da polymathía neoplatônica e neopitagórica, elementos de proveniências as mais dispares, de maneira especial concentrados nas tradições mitraicas e, obviamente, nos textos platônicos. 
Vamos enfim ao texto do Antro das Ninfas. Concentraremos nossa análise em dois dos 36 capítulos que compõem a obra, o primeiro e o oitavo, por estarem mais diretamente relacionadas à alegoria da caverna platônica.

\section{Assim começa o texto:}

A descrição do antro de Ítaca, feita por Homero nos versos seguintes, ${ }^{3}$ é enigmática:

Em cima do porto há uma oliveira de ampla folhagem:

Próxima de um belo antro, obscuro

Consagrado às Ninfas chamadas Náiades.

Nele encontram-se crateras e ânforas

De pedra; aqui as abelhas guardam o mel.

Ali estão também altos teares de pedra, onde as Ninfas

Tecem mantos purpúreos, uma maravilha para os olhos.

Aqui correm as águas eternas. Duas são as portas:

Uma, voltada para a Bóreas: é descida para os homens;

Outra, voltada para Notos: é para os deuses; por ela

Os homens não passam, mas é caminho para os imortais.

(Porfírio. O Antro das Ninfas, 1)

O restante do texto, como se dizia, é um comentário alegórico a estes 11 versos homéricos. Comentário que acompanharemos aqui, pela economia destas páginas, de forma descontínua.

Primeiramente, Porfírio, apoiado na tradição dos $\pi \alpha \lambda \alpha \iota 101$ não tem alguma dúvida em considerar o antro como símbolo do cosmo:

Os antigos consagravam apropriadamente antros e cavernas ao cosmo, considerado com um todo e em suas partes, tomando a terra como símbolo da matéria da qual o cosmo é constituído (por este motivo alguns identificavam a terra e a matéria) (Porfírio. $O$ Antro das Ninfas, 5).

\footnotetext{
3 Cf. Odisseia XIII. 102-112.
} 
A caverna é arquetipicamente imago mundi, lugar central onde se entra em contato com a matéria e as forças constitutivas do mundo. Já acenamos acima às frequentes visitas a cavernas por parte de diversas personagens antigas. Entre elas, destaca-se pela profusão de referências certamente Pitágoras: iniciado em suas ethica dogmata pela sacerdotisa Temistocléia em Delfos (fr. 15 Wehrli = 14 A 3 DK, cf. D.L. VIII, 22) a sua descida ao Hades é lembrada por Diógenes Laércio (VIII, 22 e 41). Significativamente numa destas katabáseis, Pitágoras encontra (e repreende pela impiedade) exatamente Homero (junto com Hesíodo). Porfírio (VP 9) e Jâmblico (VP 27) são unânimes em lembrar que Pitágoras havia escolhido como sua casa uma caverna, que chamava de "casa de sua filosofia" (oikéion tês eautoû philosophías). Mais um detalhe: teria sido o próprio Pitágoras, além disso, a ter cunhado primeiro o termo kósmos, atribuindo-o ao universo ordenado, em contraposição ao caos. Estamos em pleno solo pitagórico, portanto.

Mais precisamente, o antro em questão é dito ser consagrado às Ninfas, com uma referência às cavernas como lugares de culto. Porfírio lembra que os Persas já chamavam de antro o lugar onde o iniciado era conduzido para ser introduzido aos mistérios da descida das almas (AN 6), e atribui a Zoroastro a primeira consagração de um antro em templo:

Conforme Eubulos, Zoroastro primeiro consagrou uma caverna, rica de flores e fontes, nos montes próximos da Pérsia, em honra de Mitras, pai e artífice de todas as coisas: parecendo-lhe o antro o símbolo do cosmo, do qual Mitras é o demiurgo; e os objetos colocados no antro a intervalos simétricos eram símbolos dos elementos cósmicos e das regiões celestiais. Depois de Zoroastro, prevaleceu também nos outros o uso de celebrar ritos iniciáticos em antros e cavernas (Porfírio. $O$ Antro das Ninfas, 5).

Impossível não lembrar do Timeu (28c) com relação a termos como artifice e demiurgo, aqui atribuídos a Mitras. A referência é, portanto, a uma caverna de culto mitraístico, lugar de iniciação aos mistérios do zoroastrismo, mas - como a referência ao demiurgo deixa bem entrever - já helenizados pela tradição estoica (Cf. Posidônio) e depois neoplatônica. Os 
outros aos quais se refere Porfírio são certamente os cultos dionisíacos: a figura do deus Dionísio está intimamente relacionada, mesmo em Porfírio, a antros escuros e floridos (AN 5, 6, 7, 9); os mitos do nascimento do deus e de sua educação estão ligados a cavernas (SIMONINI, 2006, p. 195). Era costume, em época helenística, preparar grutas artificiais que comemoravam o nascimento do deus: tratava-se de grutas floridas, que continham, significativamente, "camas para as Ninfas" (SIMONINI, 2006, p. 195). A mitologia dionisíaca que Porfírio compreende e reconhece, perpassa, portanto a imagem da caverna de Ítaca.

A esta espeleologia mística do antro consagrado às Ninfas (a expressão é minha), se inspiraram os pitagóricos e Platão - diz Porfírio no capítulo oitavo:

Aqui - conforme acredito - se inspiraram os Pitagóricos e, depois destes, Platão, quando chamaram o cosmo de antro e caverna. Em Empédocles, de fato, as potências que conduzem as almas dizem "chegamos a este antro coberto", ${ }^{4}$ e em Platão, ${ }^{5}$ no sétimo livro de República, afirma-se "imagina, portanto, homens que estejam num antro subterrâneo, em uma casa semelhante a uma caverna, aberta em cima para a luz, e que possua uma entrada tão grande quanto toda a caverna". E quando o interlocutor exclama: "que estranha imagem descreves!", ele [Sócrates] acrescenta: "ora, caro Gláucon, é necessário referi-la a todos os discursos feitos anteriormente, e comparar o mundo que aparece aos olhos com a casa da prisão, e a luz do fogo à potência do Sol.” (Porfírio. O Antro das Ninfas, 8).

Empédocles aparece aqui com extrema eficácia, pois o fragmento citado (31 B $120 \mathrm{DK}$ ) resume a questão central da descida da alma para a geração no antro e da metemsomatose. A referência é novamente aquela de uma caverna coberta, exatamente como a de Platão. Mas de que

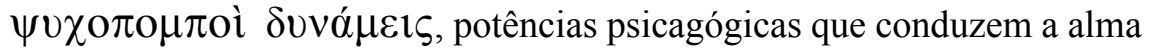
para o antro, estaria se tratando aqui? E qual é a função delas? Podemos compreender isso á luz do fr. 122 de Empédocles onde há um elenco de

\footnotetext{
${ }^{4}$ Cf. Empédocles 31B 120 DK.

${ }^{5}$ Cf. Platão. República 514a, 515a, 517a-b.
} 
duplas de Ninfas e do fr. 126, em que as potências são chamadas daímones e "revestem a alma com uma túnica", isto é, operam a metemsomatose. Empédocles movimenta-se em solo órfico, portanto. Ao mesmo tempo está aqui pressuposta, na leitura de Porfírio, toda a teoria soma-sema que aparece inicialmente na tradição pitagórica (Filolau 44 B 14 DK) e ainda mais fortemente em Platão: (Fedro 62b, 81e, 82e; Crátilo 400c; Górgias 492e; Mênon 81a; cf. CORNELLI, 2006).

Mas é obviamente a citação da imagem platônica que vai atrair maiormente nossa atenção. A mais famosa das imagens das cavernas, a de República VII, é aqui chamada em causa para confirmar a leitura místicoalegórica dos antros das Ninfas: por estes - diz Porfírio - Platão teria se inspirado na invenção de sua imagem. Como no caso de Empédocles, vários elementos parecem contribuir ao fato desta afirmação de Porfírio não ser somente uma reapropriação neoplatônica da alegoria: esta teria um valor historiográfico: Platão estaria aqui pensando sua caverna na esteira da tradição das cavernas de culto e iniciação.

Remeto para meu artigo já citado para um exame mais aprofundado desta questão(CORNELLI, 2007a). Anoto aqui somente algumas sugestões, à moda de resumo, que apontariam para a direção agora anunciada: a) na construção dramática do diálogo República está implícita a mesma imagem da katábasis, da descida: a primeira palavra, katében, desci, na boca de Sócrates, não pode ser mais clara, neste sentido: "Desci ontem ao Pireu com Glaucon, filho de Ariston, para fazer minha oração à deusa" (República I, 327a); b) a deusa em questão é Bêndis, cujo culto está ligado a divindades ctônicas como Cibele e Demetra, mas, sobretudo, a Ártemis e Hecate, filha da noite, deusa do subsolo, soberana do Hades, para onde conduz as almas (é potência psicagoga, portanto); c) a atopía proclamada por Glaucon ("que estranha imagem descreves!") pode ser irônica: estes "tipos de cavernas" (spelaiódes) deviam ser bem conhecidas tanto a Sócrates quanto a Glaucon, por se tratarem de antros reais ou artificiais devotados aos cultos acima indicados; d) um destes, certamente conhecido por Platão, é o antro ídeo, a caverna dos Curetas, dedicada a Zeus, sobre o Monte Ida, na ilha de Creta. Será citado por Porfírio em seguida (AN 20), e Platão certamente o conhecia, pois o incipit do primeiro livro das Leis faz uma referência direta à caverna em questão: narra-se que Minosse, filho de Zeus, recava-se regularmente à casa deste (isto é, ao antro ídeo) 
e legislava segundo as palavras (phemas) do Pai. Assim o diálogo Leis irá acontecer "ao longo do caminho que leva ao antro ídeo" (265b), ao templo de Zeus; e) a figura de Minosse não é a única atestada em katábasis ao antro ideo: Diógenes Laércio lembra de Epimênides, que na caverna cretense desceu e dormiu por 57 anos! (D.L. I, 109); f) Em 1984, nas mais recentes escavações na caverna do monte Ida, ${ }^{6}$ veio à luz uma cavidade, à esquerda com relação à abertura da caverna, onde foram encontradas uma lâmpada e diversos vasos alinhados sobre uma lastra. Esta lastra estava colocada toda em volta das paredes da caverna. Sinais de uma adaptação dela ao culto e à presença de numerosas oferendas, vasos e objetos ex-voto e g) na conclusão de República aparece novamente a imagem da katábasis no mito escatológico de Er, que vê duas crateras (chásmata) na terra às quais correspondem duas outras portas de entrada no céu (Resp. 614c).

A caverna é uma imagem cósmica e um lugar místico, portanto, bem antes de Platão, o tema da luz e das trevas, do itinerário de descida para o conhecimento ou para o esquecimento está desde sempre relacionado a esta enquanto se constitui como lugar de paidéia, portanto, no sentido de um itinerário de iniciação. O que Platão parece operar, todavia, alegorizando, é uma inversão desta lógica do antro, indicando neste um espaço de ignorância.

Há um paralelo platônico da caverna de República que pode iluminar melhor tanto o sentido da caverna como a exegese alegórica do antro de Porfírio: trata-se das cavernas do mito geológico do Fédon (107c-110b), pelo qual a terra é esférica e possui:

cavidades dos mais variados tamanhos e feitios, para onde confluem água, vapor e ar; quanto à terra em si mesma, em toda sua pureza, é no céu escuro que ela se encontra (...). Nós que habitamos essas cavidades estamos longe de o suspeitar, e julgamos, pelo contrário, viver em cima, na superfície da terra $(109 b)^{7}$

6 O antro foi identificado no monte Psiloritis, a cerca de $1500 \mathrm{~m}$ de altura, e é descrito da seguinte forma: "uma grande praça $(74 \times 32 \mathrm{~m})$ funcionava como vestíbulo a uma abertura de largura $25 \mathrm{~m}$ e altura $16 \mathrm{~m}$ e que levava à caverna, profunda $40 \mathrm{~m}$, larga $55 \mathrm{~m}$ e alta $30 \mathrm{~m}$ " (TORELLI-MAVROJANNIS, 1997, Idáion Antron).

7 A tradução é de Maria T. S. de Azevedo. 
O sentido da imagemé paralelo àquele da caverna de República: quem está dentro não sabe. Na esteira desta inversão platônica, porém, procede a exegese alegórica do antro das Ninfas - tanto na tradição neoplatônica em geral, com também em Porfírio - afirmando que a verdadeira terra (tên dé gên autên, a terra propriamente dita) - nas próprias palavras de Platão (Fédon 110e) - não está na caverna, e sim fora dela!

Assim, as Ninfas do antro de Ítaca são "as almas que descem para a geração (prós tên génesin) (AN 12), as crateras e as ânforas são símbolos da geração, e - diz Porfírio - "símbolos também de Dionísio, mas somente no caso em que sejam feitos de argila (...), pois são adequados ao dom do deus da videira" (AN 14). Aqui a relação entre geração e vinho pode ser ilustrada pelo testemunho de Filolau que se encontra em Proclo: "Dionísio é responsável pela geração úmida e calda, da qual o vinho é símbolo, sendo ele úmido e quente" (44 A 14 DK). Os "altos teares de pedra, onde as Ninfas tecem mantos purpúreos" são considerados, novamente, símbolo da geração:

nos seres viventes os ossos são as pedras (...) logo, os mantos purpúreos são, evidentemente a carne, isto é, o tecido que se forma a partir do sangue; (...) o corpo é portanto a túnica que envolve a alma como uma veste (PORFÍRIO. O Antro das Ninfas, 14).

Aquela do corpo como túnica (chitón) da alma é uma tradição que perpassa toda a Antiguidade. Novamente no âmbito das teorias órficas, a primeira referência encontra-se em Empédocles (31 B 126 DK), mas ainda em Platão (Górgias 523c, mas também Resp. 620c) e em Aristóteles (De Anima 407b).

Apesar do texto homérico afirmar que são as Ninfas a tecer as túnicas, Porfírio está interessado, na sua alegoria, em atribuir este trabalho do tear a Kore, que tece a geração do próprio mundo (AN 14). Kore é em seguida identificada ao mesmo tempo com Persefona e com a Lua (AN 18). Esta identificação, aparentemente inócua, é ao contrário cheia de significados para compreender a geografia mística da alegoria da caverna de Porfírio: a) a primeira identificação de Persefona, deusa do além-túmulo e "patrona de tudo o que é semeado" (AN 14) com a Lua é antiga: aparece 
já num fragmento de Epicarmo (23 B $54 \mathrm{DK}$ ): com efeito, a tradição pitagórica acompanha esta translação de Persefona para o céu: os planetas são "os cães de Persefona" e as Ilhas dos Bem-aventurados seriam o "Sol e a Lua" (Porfírio. VP 41); b) o fato é que, já na época de Empédocles, a descoberta da esfericidade da terra inviabilizou, na geografia mítica, a localização do Hades de baixo da terra; c) a relação da alma com o mundo celestial é presente já entre os filósofo jônicos no VI-V século a.C (BURKERT, 1972, p. 362).

O tear da geração das almas é, portanto, um tear cósmico: reforçase aqui a alegoria do antro como "imagem e símbolo do cosmo" (AN 21), como imago mundi: tanto o drama da metemsomatose como o da criação do mundo se dão no mesmo locus cósmico. Logo, a mudança da deusa do além-túmulo para o mundo celestial é pressuposto para compreendermos os últimos símbolos: notadamente o das duas portas de entrada na caverna, às quais Porfírio dedica uma ampla discussão, que segue por bons 10 capítulos (AN 21-31). Resumidamente, as portas são compreendidas no interior de uma extensa descrição zodiacal sobre a posição dos planetas, concluída pela afirmação que:

os teólogos consideraram como portas estes dois: o Câncer e o Capricórnio, as mesmas que Platão chamou de duas entradas (stomíai); e disseram que destas duas o Câncer é a porta pela qual descem as almas, e o Capricórnio é aquela pela qual sobem (PORFÍRIO. O Antro das Ninfas, 22).

Em seguida Porfírio cita ainda Numênio, pelo qual Parmênides teria mencionado estas mesmas duas portas (AN 23).

As duas portas do antro contribuem para a definição deste como imago mundi; na caverna estão inscritas as características daquela "verdadeira terra" à qual fizemos referência acima no mito geológico do Fédon: a verdadeira terra não é esta, e sim o mundo celestial, único que mereceu na tradição pitagórica o nome de cosmo (SIMONINI 2006, p. 193), que é a verdadeira pátria das almas, e o lugar para onde elas ascendem. O círculo hermenêutico se fecha, subida e descida, entrada e saída, caminho dos deuses e dos homens são todos símbolos deste ciclo, 
que é ao mesmo tempo da alma e do cosmo. Mas que não se trate somente de uma leitura neoplatônica, o demonstra novamente a dupla citação de Platão e de Parmênides. No caso deste último, a citação é do proêmio do Poema: Porfírio não parece ter dúvidas em considerar a viagem de Parmênides como um itinerário místico (CORNELLI, 2005). No caso de Platão, a referência é claramente ao mito de Er no final de República.

$\mathrm{O}$ que dissemos há pouco sobre a translação do Hades para o céu (notadamente no hemisfério meridional, a obra dos pitagóricos, que tomaram a idéia do Oriente, cf. Simonini 2006: 215) pode agora desvendar o símbolo das duas entradas (crateras, chásmata) do mito de $\mathrm{Er}$ (e das outras duas em correspondência destas), assim como o motivo desta referência de Porfírio (que lembra delas como stomíai, entradas): o lugar do julgamento ao qual Er assiste no mito de República, bem viu Festugiére, não é propriamente a terra, e sim uma espécie de terra mítica que está no meio do céu, entre a terra e o céu (FESTUGIÈRE 1950, III, 72, nota 2). Isto é, o mito de Er está em sintonia com esta mesma visão escatológica e cósmica à qual estamos assistindo, que desvia a katábasis do alémtúmulo para um lugar cósmico celestial, de matriz mitraística. Como prova circunstancial desta dependência - nos lembram Bidez e Cumont (1973, I, p. 109) - Colotes, discípulo de Epicuro, no III século a.C, substituia a Er o próprio Zoroastro no diálogo de República (Proclo. In Plat. Remp. $2,109)$ enquanto, segundo Crônio, Zoroastro havia sido discípulo de Er e platônico ele mesmo (SIMONINI, 2006, p. 196).

É que a metemsomatose se dá num espaço agora celestial, do qual, todavia, o antro é ainda símbolo, resta claro no capítulo 28 do Antro das Ninfas, pelo qual sabemos que Pitágoras referia-se às almas em movimento como a "povo de sonhos":

Para Pitágoras as almas são povos de sonhos, que, ele diz, se reúnem na Via Láctea, assim chamada por causa das almas que, quando caídas na geração, se nutrem de leite (PORFÍRIO. O Antro das Ninfas, 28).

Aliás, de leite e mel: sendo desta forma (mas não somente desta forma) explicado o simbolismo das abelhas dos versos homéricos. O âmbito de referência desta metemsomatose é novamente órfico: numa lâmina de 
ouro órfica descoberta recentemente em Thurii a alma declara: "cabrito te jogaste no leite" (PUGLIESE-CARRATELLI, 2001, p. 103 e 113).

O último símbolo a ser desvendado é exatamente o primeiro dos versos homéricos, isto é, a imagem da oliveira. Ela "abraça e dá unidade ao inteiro enigma do antro" (AN 32) - diz Porfírio. É uma árvore consagrada a Atenas, deusa da sabedoria (phrónesis), que por sua vez rege o cosmo, fechando assim o círculo hermenêutico novamente no antro como imago mundi. É também dada aos atletas vencedores em formato de coroa, assim como da phrónesis do cosmo "derivam os prêmios da vitória aos atletas da vida (athlétai tô̂ bíou) e o remédio que alivia as infinitas penas" (AN 33). No final do texto de Porfírio, o próprio Odisseu e sua jornada são assumidos como símbolo último do drama da alma:

Chegados a este antro - diz Homero - é necessário abandonar toda posse estrangeira, e ficando nús, assumir o aspecto de um mendigo, exaurindo o corpo, jogando fora tudo o que é supérfluo, afastar-se das sensações, e então deliberar (bouleúetai) com Atenas sentado com ela aos pés da oliveira, sobre como eliminar todas as paixões que afetam a alma (PORFÍRIO. O Antro das Ninfas, 33).

A nudez é típica dos rituais de iniciação, e a imagem poética de Atenas aconselhando Odisseu de baixo da oliveira é motivo ético, frequentemente explorado pela filosofia neoplatônica, enquanto símbolo da divinização da alma.

Referindo-se mais uma vez à interpretação alegórica de Numênio, Porfírio diz ser Odisseu "imagem daquele que atravessa todos os estágios da geração" (AN 34), resumindo em si os dois temas centrais da sua exegese: o da a alma que passa pela geração e do retorno para a verdadeira pátria.

O tema do retorno em pátria é fortemente presente no pensamento neoplatônico. Porfírio, no De Abstinência, afirma: "nós parecemos homens que, voluntariamente ou não, emigraram junto a um povo de uma raça diferente" $(1,30,2)$. Plotino exorta na primeira Enéada $(1,6,8)$ : "fujamos para nossa verdadeira pátria, como Odisseu". 


\section{Conclusão}

Em conclusão, quase que a querer defender-se antecipadamente das críticas de superinterpretação, Porfírio assegura:

Não se deve pensar que estas exegeses sejam forçadas ou fruto das invenções de quem rende os discursos plausíveis: (...) não se pode não reconhecer que [Homero] escondeu imagens de coisas mais divinas sob a ficção de uma fábula; pois não teria conseguido construir a inteira narrativa, se não estivesse baseada em alguma verdade para moldar sua ficção (PORFÍRIO. O Antro das Ninfas, 36).

Isto é, o que Homero diz é com certeza uma ficção, mas uma ficção construída sobre tís alétheia, alguma verdade.

A recepção porfiriana, de estampo notadamente alegórico, portanto, não apaga, todavia, os traços de alguma verdade que, historiograficamente, diz da filosofia e de suas andanças pelas cavernas. Ainda que o trabalho historiográfico não tenha a beleza e a liberdade da construção alegórica, o percurso pela exegese neoplatônica revela referências à cultura antiga ricas de sugestões para uma leitura de amplo fôlego dos textos platônicos. Em resumo, a lectio porfiriana permite, neste caso, compreender que a imagem da caverna de República revela algo mais que uma simples alegoria, sugerindo a existência de relações dialógicas e circulares entre a filosofia platônica e o imaginário religioso e da cultura popular do mundo antigo.

O leque de dependências e circularidades de temas, conceitos, imagens é muito amplo, mesmo assim, se não quisermos ler Platão com a pobreza de uma abordagem exclusivamente analítica, todas elas devem ser exploradas até suas últimas consequências.

\section{Referências}

ATKINSON, M. Plotinus. Ennead. Oxford: Oxford University Press. 1983 BETEGH, G.. The Derveni Papyrus. Cosmology, Theology, and Interpretation, Cambridge: Cambridge University Press, 2004. 
BERNABÉ, A. Orphisme et Présocratiques: bilan et perspectives d'un dialogue complexe. In: LAKS, A; LOUGET, C. (Ed.). Qu'est-ce que la philosophie présocratique? What is presocratic philosophy? Presses Universitaires du Septentrion, Villeneuve d'Ascq, 2002.

. L'âme après la mort : modèles orphiques et transposition platonicienne'. In: PRADEAU, J. F (Ed.). Études platoniciennes IV, Les puissances de l'âme selon Platon, Les Belles Lettres, Paris, p. 25-44. $2007 \mathrm{a}$.

BIDEZ, J. Vie de Porphyre. Le philosophe neo-platonicien. 43. ed. New York: Georg Olms Verlag, 1980.

BIDEZ, J.; CUMONT, F. Les mages hellénisés. Paris, 1973.

BURKERT, W. Craft versus Sect: The Problem of Orphics and Pythagoreans. MEYER, B. F.; SANDERS, E. P. Jewish and Christian Selfdefinition. Philadelphia: Fortress Press, 1982. p. 1-22.

.'La teogonia originale di Orfeo secondo il Papiro di Derveni'. In: GUIDORIZZI, G.; MELOTTI, M. (Ed.). Orfeo e le sue metamorfosi: mito, arte e poesia. Roma: Carocci, 2005. p. 46-64.

CORNELLI, G. O caminho de Parmênides: sobre filosofia e katábasis no Prólogo do Poema'. Hypnos, São Paulo, v. 14, p. 23-45, 2005.

- 'Metempsicosis y anamnesis: el diálogo platónico con las tradiciones religiosas de su tiempo'. Limes, Santiago, v. 16, p. 47-59, 2006. . 'Filosofia Antiga Underground: da Katábasis ao Hades à Caverna de Platão'. REVER, ano 7, p. 94-107, 2007b.

Derveni Papyrus, The. Edited with Introduction and Commentary by Theokritos Kouremenos, George M. Parássoglou Kyriakos Tsantsanoglou. Studi e testi per il «Corpus dei papiri filosofici greci e latini», vol. 13, 2006.

EUSÉBIO. História Eclesiástica. Coleção Patrística. São Paulo: Paulus, 2000.

EUSEBIUS. Preparation for the Gospel. Tradução de Edwin Hamilton Gifford. Oxford: Clarendon Press, 1903. 
FESTUGIÉRE, A-J. Contemplation et Vie Contemplative selon Platon. Paris: Vrin. 1950.

GAZZINELLI, G. Fragmentos órficos. Belo Horizonte: Editora UFMG, 2007.

GIAMBLICO. La vita pitagorica. A cura di L. Monteneri. Roma/Bari: Laterza, 1994.

HANKEY, W. Neoplatonism and Contemporary French Philosophy, Dionysius, Paris, v. 23, p. 161-189, 2005

HAVELOCK, E. Parmenides and Odysseus. Harvard Studies in Classical Philology, v. 63, p. 133-143,. 1958.

HUFFMAN, C. A. Philolaus of Cróton: Pythagorean and Presocratic. A Commentary on the Fragments and Testimonia with Interpretative Essays. Cambridge: Cambridge University. Press, 1993

KINGSLEY, P. Ancient Philosophy, Mystery and Magic: Empedocles and the Pythagorean Tradition. Oxford: Clarendon Press, 1995.

LAKS, A.; MOST, G. W. Studies on the Derveni Papyrus. Oxford: Oxford University Press, 1997.

MORRISON, J.S. Parmenides and Er. The Journal of Hellenic Studies, New York, v. LXXV, p. 59-68, 1955.

MUNIZ, F. A Odisseia de Parmênides. Anais de Filosofia Clássica, v. 1, n. 1, p. 37-44. 2007.

PITAGORA. Le opere e le testimonianze. A cura di M. Giangiulio. Milano: Mondadori, 2000.

PLATONE. Tutti gli scritti. A cura di Giovanni Reale. Milano: Rusconi, 1991.

PUGLIESE CARRATELLI, G. Le lamine d'oro orfiche: istruzioni per il viaggio oltremondano degli iniziati greci. Milano: Adelphi, 2001.

SIMONINI, L. Porfirio. L'antro delle ninfe. Milano: Adelphi, 2006.

TORELLI, M.; MAVROJANNIS, T. Grecia. Milano: Mondadori. 1997

TORTORELLIGHIDINI,M.Figlidellaterraedelcielostellato:testiorficicon traduzione e commento. Napoli: M. D’Auria, 2006. 
.; MARINO, A. S.; VISCONTI, A. Tra Orfeo e Pitagora: origini e incontri di culture nell'antichità. Atti dei seminari napoletani 1996-98. Napoli: Bibliopolis, p. 397-412.

TURCAN, R.Mithras Platonicus. Leiden: E.J. Brill. 1975.

Data de registro: $22 / 06 / 2010$ Data de aceite: 16/02/2011 